\title{
Geology and environmental change: a New Brunswick perspective
}

\author{
A.G. Pronk \\ Geological Survey Branch, Mineral Resources Division, Department of Natural Resources and Energy, \\ P.O. Box 6000, Fredericton, New Brunswick, E3B 5HI Canada
}

\author{
Date Received April 17, 1991 \\ Date Accepted July 3, 1991
}

\begin{abstract}
Studies of earth cycles are used in a variety of ways, from mineral exploration to recording and explaining past, and projecting future climate change. Geology helps us find the commodities we need to accommodate our lifestyles, to assess natural hazards, find drinking water and safe places to dispose of our waste. As mankind will search for a way to achieve a globally sustainable society, the limits of this planet will have to be acknowledged. Geology is one of the disciplines that can help us understand our planet and establish those limits. Further research in the earth sciences is required to clarify our present knowledge of the environment, quantify many processes, and define limits of prediction for future change.
\end{abstract}

L'étude de la rythmicité terrestre est mise à contribution de diverses manières allant de l'exploration minière à l'élucidation des changements climatiques anciens ainsi qu'à la prospective climatologique. La géologie nous aide à trouver les matières premières indispensables aux besoins qu'engendre notre style de vie, à évaluer les risques naturels, à trouver de l'eau potable, et à identifier des sites sécuritaires pour le stockage des déchets. La mise en oeuvre par l'humanité de moyens visant à réaliser une société au maintien durable à l'échelle du globe devra s'accompagner d'une prise de conscience des limites d'emploi de notre planète. La géologie est l'une des disciplines pouvant contribuer à affiner notre connaissance de la Terre et à cerner au plus près ces limites. Un effort additionnel de recherche en sciences de la terre s'impose afin d'approfondir notre connaissance de l'environnement, de quantifier plusieurs processus et d'établir les limites gouvernant notre capacité de prédire les changements à venir.

[Traduit par le journal]

\section{INTRODUCTION}

Exploration, extraction and management of natural resources is directly related to geology. Our environment is the result of interactions between the geological, hydrological, and biological cycles. The different time scales on which these cycles operate, and the different turn over rates of their reservoirs and sinks, affect the temperature, atmospheric composition, and the overall habitability of this planet for Homo sapiens and other lifeforms. Long-term geological cycles operate beyond the human time scale. Medium-term cycles are relatively easy to adapt to and anticipate, but it is the short-term changes that really affect us and that we in turn can influence. Man has become a geological force! Any changes that have occurred since mankind has inhabited the earth have taken place gradually enough, until recently, for us to adapt to.

Man's philosophical/religious assumption that his place is outside and above nature, and the actions that are the result of this, are beginning to have their effect. The indiscriminant use of natural resources and the production of synthetic materials is heavily burdening our ecological system.

Many of the products and conveniences of our consumer society are directly or indirectly related to mineral resources and geological knowledge. I will discuss some of the obvious and not so obvious relations, with New Brunswick examples, in the second part of this paper. To make the needed changes in our behavior, we need to understand long and short term changes in the natural world. Geology is, in essence, the sum of environment and time, and as such, lays the basis for a sustainable society. Earth scientists will have to educate the general public about the planet we all live on in order to make informed and rational decisions on these issues (see Mungall and McLaren, 1990). When all is said and done, it will be a moral question of how we will eventually want to reach our new equilibrium.

\section{Geology and Global Change (Warming)}

\section{The carbon cycle}

One of the issues of global importance that everyone has to deal with is global warming and its suggested cause, the greenhouse effect. In the following review, some of the issues related to global change will be examined from a geological perspective. Carbon dioxide and methane are two of the important greenhouse gases. These gases are both part of the global carbon cycle, and will be used as an example of 
how geology relates to this issue. It is also relevant that the coming of a new glacial period is considered to lie in the "near" future (Veevers, 1990; Fig. 1). Thus, we are looking at the present warming on a very short time scale.

Both carbon and oxygen are among the more stable elements in the universe and play an important role in life as we know it (Gribbin and Rees, 1989). It is therefore ironic that, when linked chemically, these elements are now giving us problems. The carbon cycle can be divided into the biological and the geological cycles. The former involves small reservoirs and sinks, but can adapt over relatively short time periods, whereas the latter has vast reservoirs, with long periods needed for transfers from one sink to another (Berner and Lasaga, 1989; Fig. 2). Throughout geological history, and also mankind's presence, the carbon dioxide levels in the atmosphere have fluctuated considerably. To understand the anthropogenic influenced climatic change, we first have to understand the natural state and its fluctuations.

Climate fluctuations take place on a wide range of time scales. Super cycles have been used to explain long period cyclicity in sea level, magma emplacement and formation of mineral deposits (Veevers, 1990). Recently Veevers (1990) has put all stratigraphic, sea level, magma emplacement, and magnetic data into a theory of a tectonic-climatic supercycle. The theory attempts to explain many features in the stratigraphic record of the last 1100 million years. Veevers assumes the formation and break up of the Pangean supercontinent drives the global carbon dioxide cycle, that in turn triggers the ice house/green house super cycle. The period of this cycle is $\mathbf{4 0 0}$ million years, in which the ice house lasts for $\mathbf{1 5 0}$ million years, and the green house state 250 million years. Within the green house state there is a period in which the green house overshoots and glacial conditions occur while the continents are scattered over the entire globe. The cycle has five stages of development: (1) formation of Pangea, accumulation of heat under the insulating continent, build up of ice sheet, general cooling of the atmosphere; (2) thinning of the continent, basin formation; (3) rifting of the continent, start of carbon dioxide release; (4) continental drift, fast sea floor spreading, and massive release of Pangean heat; and (5) younger drift sequence, slower heat loss, slow spreading and subduction. The cycle closes with the confluence of the continents into one Pangea-like landmass.

Today, we are in the ice age phase of a green house state due to the overshooting of the greenhouse effect. This means that the earth's present state is naturally rare, and that our own presence and influence has made it unique.

Superimposed on this super cycle, are the Milankovitch cycles that are determined by the sun/earth interactions and the earth's surface heat balance (Fig. 3). Milankovitch cycles are governed by the earth's orbit around the sun (from a flat eliptical to a round eliptical one, in a 100,000 year cycle), and the angle of the earth's axis in relation to its orbital plane, that ranges from 21.5 to 24.5 degrees (a 41,000 year cycle). This

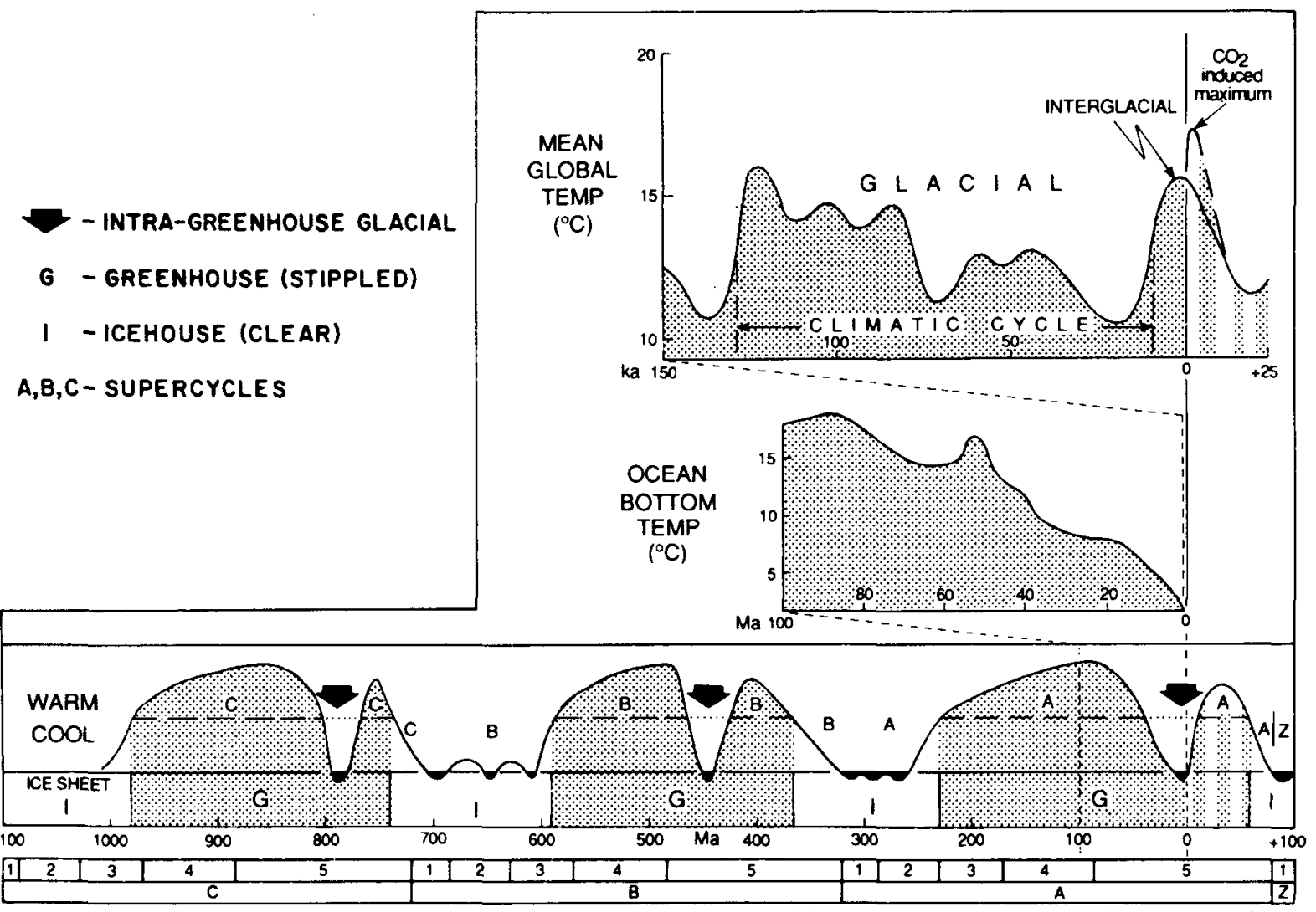

Fig. 1. Rock cycles influence ice and climate cycles. From Veevers (1990), who places global climatic change into a long term geologic perspective. Note different time scales in the three curves. 


\begin{tabular}{||l|c|c||}
\hline \multicolumn{1}{|c|}{$\begin{array}{c}\text { CARBON RESIDENCE } \\
\text { (FORM) }\end{array}$} & $\begin{array}{c}\text { CARBON MASS } \\
\left(\mathbf{1 0}^{\mathbf{1 8}} \text { GRAMS) }\right.\end{array}$ & $\begin{array}{c}\text { RELATIVE TO } \\
\text { LIFE (=1) }\end{array}$ \\
\hline Calcium carbonate (mostly in sedimentary rocks) & 35,000 & 62,500 \\
Ca-Mg carbonate (mostly in sedimentary rocks) & 25,000 & 44,600 \\
Sedimentary organic matter (as kerogen) & 15,000 & 26,800 \\
Oceanic dissolved bicarbonate and carbonate & 42 & 75 \\
Recoverable fossils fuels (coal and oil) & 4.0 & 7.1 \\
\hline Dead surficial carbon (humus, caliche, etc.) & 3.0 & 5.4 \\
Atmospheric carbon dioxide & 0.72 & 1.3 \\
All life (plants and animals) & 0.56 & 1 \\
\hline
\end{tabular}

Fig. 2. Carbon reservoirs of the "fossil" and "present" carbon cycle, and their masses. The small amount of carbon in "short term active" sinks can be thoroughly "disturbed" by fossil carbon. The line separating the sinks of the two cycles is artificial, since the different cycles are inseparable, as we have found out. Adapted from Berner and Lasaga (1989).

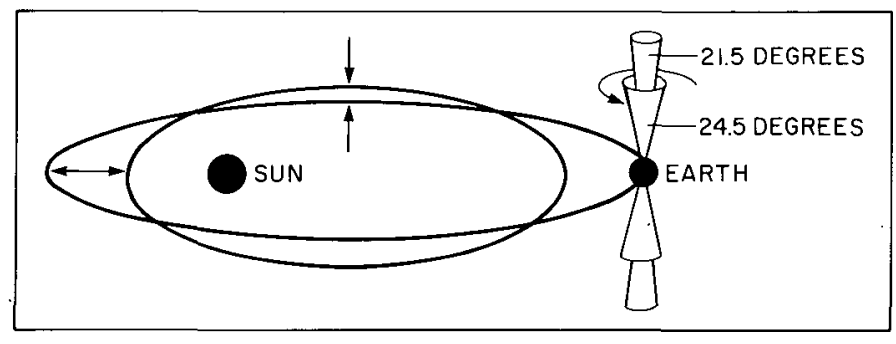

Fig. 3. The forcing of Quaternary glacial cycles can be largely explained by the Milankovitch cycles, that govern fluctuations in the sun/earth system, and determine the earth's total received radiation budget. Adapted from Broecker and Denton (1990).

is further affected by a wobble of the earth's axis every 23,000 years (Berger, 1988). These cycles determine the solar heat influx at high northern latitudes and can account for $75 \%$ of the Pleistocene climatic variations (Broecker and Denton, 1990). Broecker and Denton also argue that glacial and interglacial conditions represent two stable but very different modes of ocean/atmosphere interactions. They also question if we could flip the system into an entirely different mode by our own interference. It is clear from a review of the above cycles, that there is much that we do not yet know about natural cycles (e.g., Lindzen, 1990; Schneider, 1990; Fyfe, 1990a).

Limits to our present knowledge of active carbon sinks is illustrated by the fact that we cannot account for half the fossil carbon we have put into the air since the industrial revolution. It has also been suggested that we should not consider carbon dioxide as a pollutant, since we breathe it out with every breath.

The global experiments of greenhouse warming and ozone depletion that are presently ongoing (Fyfe, 1990b; Weiner, 1990) should make us reassess our use of our natural resources. This ultimately should result in an attempt to live within the limits set by our environment.

\section{Geology and Our Everyday Lives}

Geology includes the study of the mineral and grain size compositions of bedrock and overburden, which in turn determine nutrient potential, relief, surface accessibility, drainage, $\mathrm{pH}$, and weatherability. These characteristics in turn determine the soil type, and ultimately, the landuse (e.g., Ruitenberg and McCutcheon, 1983). Recent developments in analytical chemistry make it possible to determine many elements in concentrations of parts per trillion ( $p t t)$. This has improved our knowledge of trace elements in rocks, waters, soils, and food. For a more thorough discussion of trace element geochemistry and health issues, see Bowie and Thornton (1985) and Crounse (1986).

Sustainable land use, hazard mapping, and a more holistic approach to health care, will increase the importance of agrogeology and trace-element studies for soils and drinking water (see sections on agrogeology and drinking water). Much of the geological data are already available for these purposes. 


\section{The Mineral IndUSTRY}

Most people take for granted the luxuries that surround them and do not know much about the origin of the materials used in their manufacture. As Robert Ginn (past president, Prospectors and Developers Association of Canada) put it in a speech; "Do we need minerals? Only if we want buildings, ships, airplanes, cars, glass windows, plates, cutlery, machinery, communications equipment, energy, and other such items in our lives. Each year each of us in North America needs 40,000 pounds of new minerals (U.S. Bureau of Mines). If less developed countries are to improve their standard of living, the per capita need will be greater". Higher concentrations of minerals give rise to geochemical and geophysical anomalies. Most geoscientists are familiar with the use of stream sediment geochemistry as a method to identify areas of mineral potential (see Hawkes and Webb, 1962, for New Brunswick examples). Other methods such as magnetic, gravity, and radiometric surveys, combined with basic geological mapping, may reveal anomalies that may indicate economic concentrations of useful minerals. Following up on anomalies focusses exploration on a smaller target area, and may call for trenching or diamond drilling. Detailed stratigraphic, mineralogic, and geochemical studies follow, to determine both economic and physical characteristics of the prospect. Layout and planning of the mine, milling circuit, settling ponds, etc., all rely on properly gathered geological and geotechnical information. An Environmental Impact Assessment (EIA) has to be carried out, and if the deposit warrants it, a refinery or smelter may be built. The people that buy the final products, from cars to water pipes, from cutlery to "tin" cans, and from bricks to fertilizers, are generally unaware of the geological knowledge that was needed to find and to produce these items. It is our job to inform the general public so they will not only appreciate geology but will also realize that these products exact a high price from the environment in which they live.

For metals like aluminium, lead, copper, iron, and steel, between 30 and 50\% (Institute of Scrap Recycling Industries) finds its way back into the recycling stream in North America, and this percentage is growing. This will not take away the need for "fresh" metals, but people will perhaps begin to treat these resources with more respect. Production of metals is becoming more expensive, since environmental controls on mining and processing ventures are becoming more stringent. This is already translating into a more efficient and cleaner mineral industry. Reclamation plans have to be in place even before production can start. In central New Brunswick contouring and biomass application in the Minto coal mining area will make stripmined lands again suitable for forestry.

Both oil fields and mineral deposits contain naturally high concentrations of certain elements that will be released into the environment at an unnaturally fast rate when we exploit them. If we, as a society, require those materials, we have to be aware of the consequences. We do have the option and the technology to keep the release of these elements at an acceptable level for all living species, but there is a cost involved. In many instances clean up of old mining sites involves the mining of old waste dumps and tailings with new technology that will extract more of the ore elements. These operations can be profitable and thus help pay for the cleanup process. In some instances closure of a mining operation may create more problems (e.g., acid drainage) instead of solving existing ones. The new emphasis in mining should be on the generation of the least possible amount of waste and the control of effluents to the extent that only biologically safe levels of trace elements are released into the environment. As indicated on the periodic table (Fig. 4), most potentially toxic elements are also of economic importance.

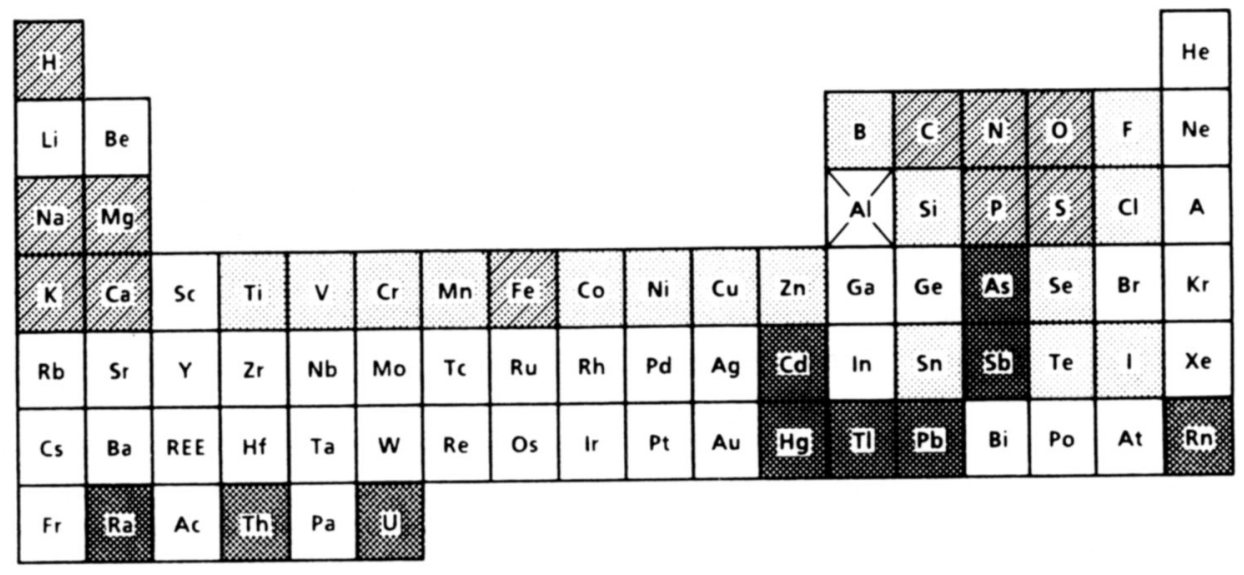

BIOACTIVE ELEMENTS
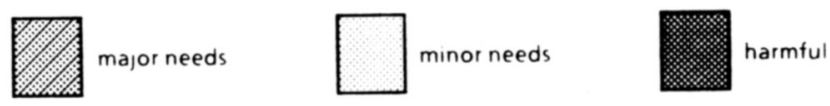

Fig. 4. Elements of the periodic table which are known to be biologically active. $\mathrm{Al}$ is marked with an $\mathrm{X}$ to indicate that its influence is uncertain. (after Darnley, 1990). 
It is only a matter of weighing the importance of our environment against the cost of extracting these elements. This is a moral choice, not an economic or a scientific one, that we as individuals and as a society will have to make.

\section{Drinking Water}

Most people are unaware of the role geology plays both in the location and protection of our (drinking) water resources, yet many know that water is also a natural resource and is essential to all life. Water quality and quantity is commonly in the news and is a major concern to many people. Two main issues should be addressed in protecting our drinking water sources. One is the clean up of contaminated soils, mainly around gasoline service stations and industrial complexes. Treatment of these materials by leaching and/or bacteriological processes (mining technology!) can make them fit to be returned in situ. The other issue is the protection of ground water recharge areas and the planning aspects of this protection. In both cases geological information is essential in making decisions and recommendations. There is another issue, however, that is especially important for domestic water wells, and that is the natural presence of many trace elements.

In glaciated terrain many aquifers in unconsolidated glaciofluvial deposits are also quarried for aggregate. In New Brunswick, quarries of this kind were also historically used for local waste dumps. The irony is that the unconsolidated quarriable material is also part of an aquifer, which allows contaminants to flow freely. This is why Sussex Corner lost its original water supply. In search for a new high quality municipal water supply for Sussex Corner, geological information was used to locate potential sites for a new well (A.A. Ruitenberg, personal communication, 1990). Detailed mapping of bedrock stratigraphy and structure followed by limited geophysical work permitted rapid and accurate location of drill sites, which provided access to a prolific aquifer (Fig. $5)$. Water supply problems in other parts of the Carboniferous Basin were not solved so smoothly, since detailed geological information was not available.

A related issue is the location of the new generation of Regional Sanitary Landfill Sites for New Brunswick. These sites have to be located in areas where both normal operation and possible accidental spills will have the least impact on the surrounding areas and the local water resources. Aquifer recharge areas are characterized by low volume surface flow and high infiltration rates and should be avoided in locating these landfill sites. The main focus should then be on significant structural and other geological constraints placed on certain sites by local overburden and bedrock geology parameters like permeability, areas of confluence, etc., (A.A. Ruitenberg, personal communication, 1991).

Understanding the recharge of the Fredericton Aquifer (Fig. 6) is of utmost importance in establishing planning and zoning regulations in the well field area and effluent regulations up river. Most of downtown Fredericton is situated on an ancient alluvial terrace, underlain by glaciofluvial and

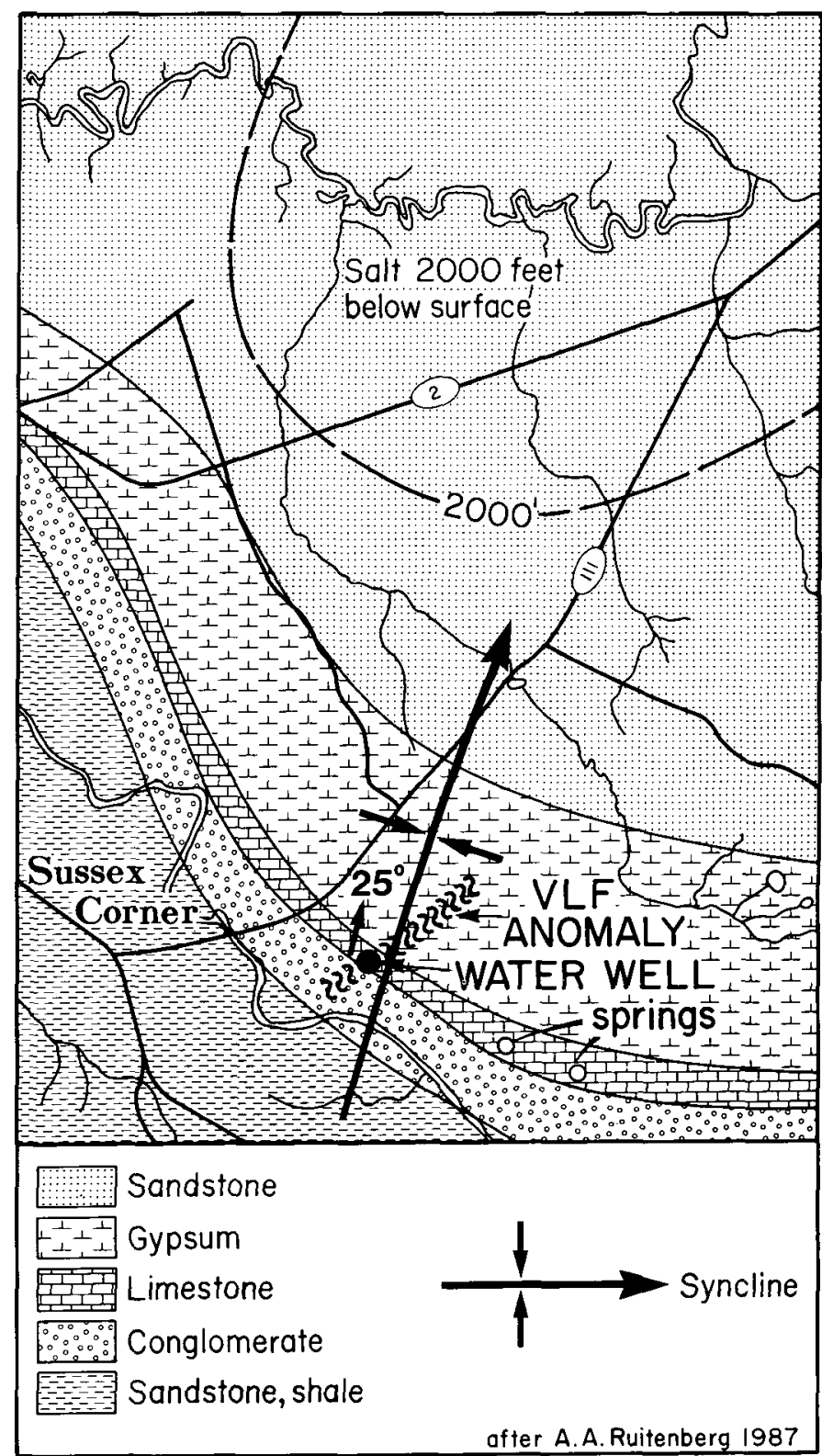

Fig. 5. The location of the new water well for Sussex Corner, and its relation to geological structures. Detailed mapping by local geologists was indispensable in finding this new water supply (A.A. Ruitenberg, personal communication, 1990).

lacustrine sediments. The aquifer itself is thought to be a buried esker or sequence of ice contact deltas and underlies part of the terrace. The recharge of the aquifer is now thought to be predominantly directly from the Saint John River (Violette and Bray, 1991). The water flows through "windows" in the clay silt unit from the river into the sand and gravel body where the water is filtered through the sediments. The filtering capacity of the aquifer is not unlimited, and we should look seriously at discharges into the river. Dilution of effluents is only acceptable to a certain point and only for naturally occurring substances. Dilution is not the solution to pollution.

Determination of the transport and extent of contami- 


\section{FREDERICTON AQUIFER}

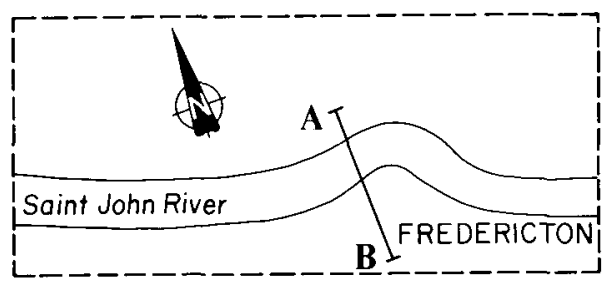

A

LEGEND

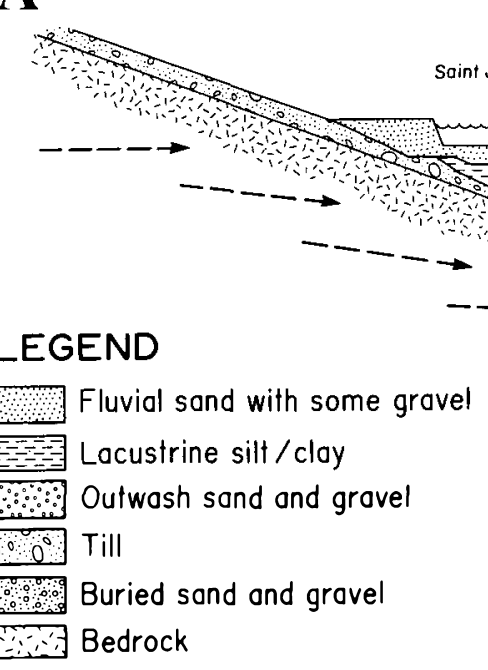

$\rightarrow \quad \begin{aligned} & \text { Direction of local groundwater flow } \\ & -\rightarrow-\text { Direction of regional groundwater flow }\end{aligned}$

Modified from unpublished report, G.G. Violetle. Groundwater Sludies Group, U.N.B

Fig. 6. Recharge of the Fredericton Aquifer as interpreted by the UNB Groundwater Studies Group (Violette and Bray, 1991). The location, structure, and recharge of the aquifer indicates the need for careful planning.

nated ground water also relies on geological investigations. The acidity of the ground water depends on the bedrock and the acidity of the rain. In this environment, acid rain makes many "toxic" trace elements, like arsenic, zinc, cadmium, and mercury, more mobile. The presence of trace elements in drinking water can be either beneficial or detrimental to human health and to the health of cattle, crops, and trees. Trace element supplements in animal feed is a long established health measure, but although we know the effects on man, it is still not widely applied. Elements such as $\mathrm{Fe}, \mathrm{I}, \mathrm{Cu}$, $\mathrm{Zn}, \mathrm{S}, \mathrm{Na}, \mathrm{Mo}, \mathrm{Se}$, are all essential in specific doses for good health. The connection between thyroid problems and I deficiency, and anemia and $\mathrm{Fe}, \mathrm{Cu}$ deficiency are well known. Many metals are essential in enzymes. The role of cobalt in many metabolic functions has been known for a long time, as is the role of selenium in mammal muscular development (Crounse, 1986). Although the significance of fluorine is still under investigation, its importance in human metabolism seems certain. Both deficiencies and high doses of fluorine are detrimental to our health. High doses can result in dental, or even skeletal fluorosis (bone fusion), whereas too low an intake will result in dental caries, and even poor bone development. On the other hand, higher than average fluorine intake may protect a certain group from osteoporosis. The beneficial fluorine range is between 1.3 and 2.0 milligrams per day (Fig. 7), which can be obtained partly through our diet and our drinking water (D. Boyle, personal communication, 1991).

\section{Geothermal Energy}

The heat locked up in the earth is enormous and is continually emitted into the atmosphere and into space. In the earth's crust temperatures increase by $1-3^{\circ} \mathrm{C} / 100 \mathrm{~m}$ (temperature gradient), depending on rocktype and age. In the mantle, this hydrothermal gradient is only $1-2^{\circ} \mathrm{C} / 1000 \mathrm{~m}$. At the crust/mantle boundary, at $30-35 \mathrm{~km}$ depth, the temperature is in the order of $1000^{\circ} \mathrm{C}$. The internal heat of the earth 
FLUORINE AND HUMAN HEALTH

\begin{tabular}{|c|c|c|c|}
\hline \multicolumn{2}{|r|}{ HEALTH EFFECTS } & \multicolumn{2}{|c|}{ SAFE INTAKES } \\
\hline mg/day & Symptoms & age & mg/day \\
\hline 0 & Death - Skeletal System Collapse & $0-0.5$ & $0.1-0.5$ \\
\hline $0-0.5$ & Poor Bone Development & $0.5-1$ & $0.2-1.0$ \\
\hline $0.5-1.3$ & Dental Caries & $1-3$ & $0.5-1.5$ \\
\hline $1.3-2$ & Optimum Benefit & $4-6$ & $1.0-2.5$ \\
\hline $2-5$ & Dental Fluorosis (Mottling) & $7-10$ & $1.5-2.5$ \\
\hline $5-10$ & $\begin{array}{l}\text { Skeletal Fluorosis (Bone Fusion) } \\
\text { Protection from Osteoporosis? }\end{array}$ & $11+$ & $1.5-2.5$ \\
\hline $10-40$ & Severe Toxity & Adult & $1.4-4.0$ \\
\hline$>40$ & Death - Poisoning & & \\
\hline
\end{tabular}

Fig. 7. Fluorine is a good example of the influence of trace elements on our health. The element has a specific concentration range that is beneficial to our health, values above and below this range can be detrimental to our health (D. Boyle, personal communication, 1991 ).

is produced by nuclear fission reactions in the earth's core and is in the form of radiation. We are shielded from most radiation by a thick crust. If we could tap into this almost endless energy reservoir, we could rely on geothermally generated electricity and steam for most of our energy needs (Fig. 8).

The use of domestic heat pumps taps into the heat reservoir of our ground water and heats buildings in the winter and cools them in the summer. Recently larger scale heat pump/exchange systems have been built for instituitions (e.g., Carlton University in Ottawa; Fig. 9) and small communities. Old flooded mine shafts are perfect sources of groundwater for this type of heat pump system (e.g., Springhill coal mines, N.S.). Although not a complete solution to our energy problems, it is part of the solution and is a cheap and almost endless source of energy.

In Iceland most energy comes directly or indirectly from geothermal sources that are at or close to the earth's surface. In North America, pilot plants have been operating (New Mexico and California) but cannot economically compete as yet with other energy sources. True alternate energy sources for a sustainable society will have to take all short and long term costs into consideration.

The use of fossil fuels is in many ways wasteful. The "flaring" of oil wells, the inefficiency of fossil fuel burning generating plants, and the manufacturing of disposable items out of oil are just some of the issues. Carbon dioxide, nitrous and nitrogen oxides, sulphur dioxide, are products of fossil fuel burning and contribute to both air pollution and the greenhouse effect. Resulting high summer temperatures may result in increased use of air conditioners, which in turn will put more greenhouse gases into the air.

Scrubber technology can only solve some of the problems associated with the burning of coal. Limestone in the scrubbers absorbs the sulphur dioxide, and the end product (gypsum) may actually be marketable. New local sources of limestone for the Belledune (northern New Brunswick) scrubbers are being evaluated. Hydro projects, that also partly rely on geological information, have associated environmental costs too. In Canada, with our colder than average climate, larger than average distances, and energy intensive resource industries, energy conservation in itself would be economically worthwhile, even without the environmental benefits. There are no environmental costs to energy conservation, whereas all conventional energy sources have these costs associated with them.

\section{Agrogeology}

The characteristics and properties of rocks and rock derivatives are of great importance to both agriculture and forestry. The bedrock and overlying transported or in situ 


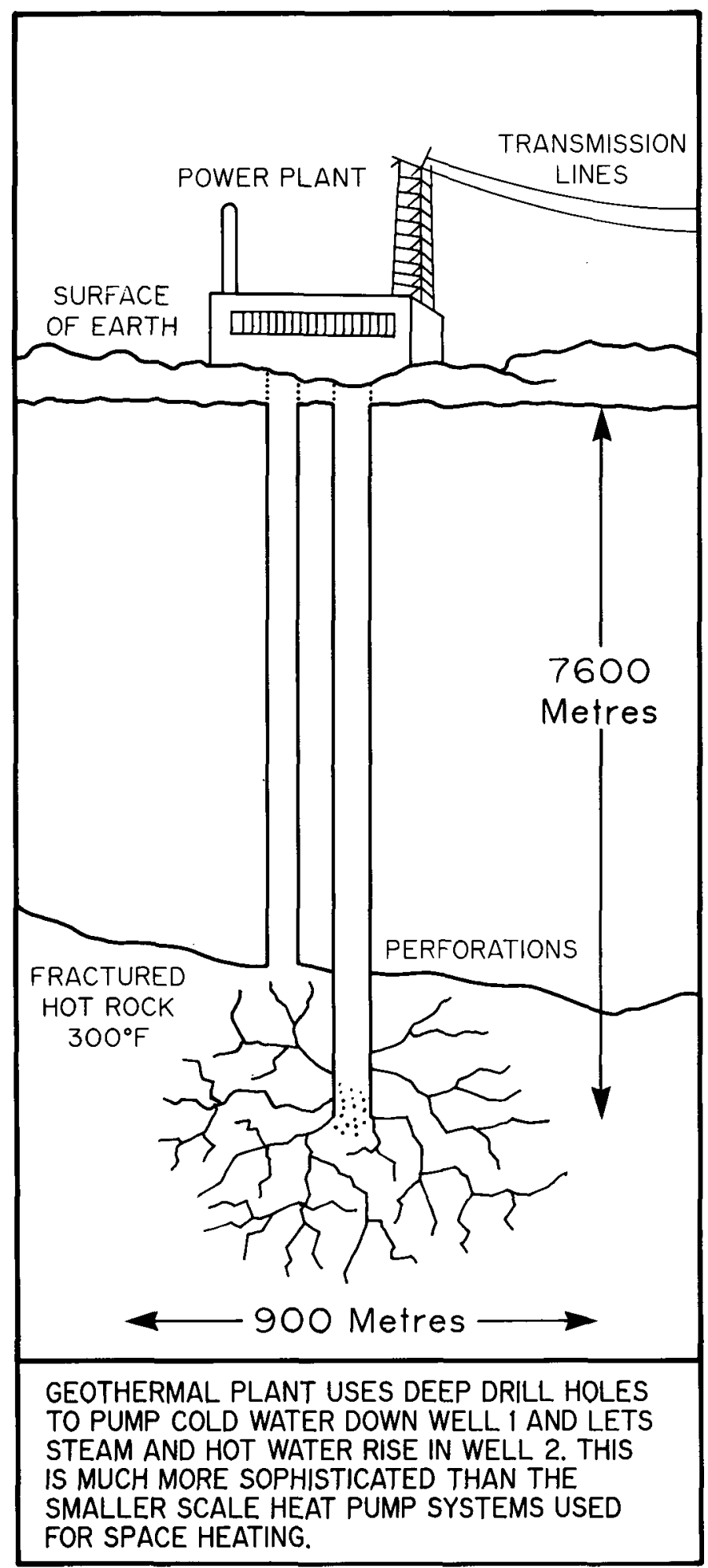

Fig. 8. The earth itself is a great source of energy, and if we could tap into this energy source, we would solve at least part of our energy problems. The earth warms up $\pm 2.5^{\circ} \mathrm{C} / 100 \mathrm{~m}$ depth in the average crust. This schematic diagram of a pilot plant in Alamos, New Mexico, shows one of the possibilities.

overburden determine properties such as relief, weatherability, nutrient potential, pH of soil and ground water, soil formation and drainage. Rocks lie at the base of all food

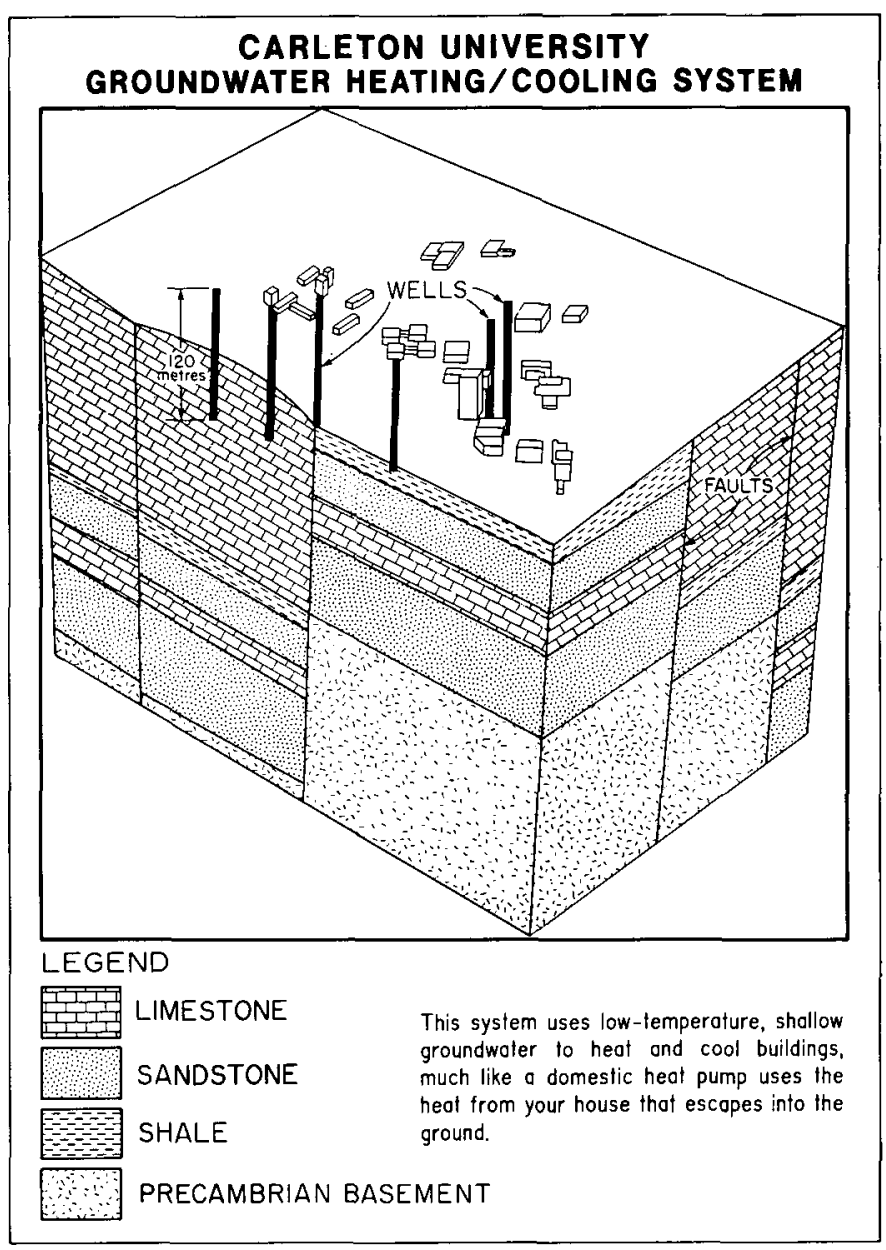

Fig. 9. Carleton University heating/cooling system, slightly simplified from Thiessen (1990).

chains. The biosphere is limited by the geosphere, climate, and its interactions. One perfect example of this relationship is the distribution of peat resources in New Brunswick (Fig. 10). The distribution is a direct result of poor nutrient potential, and poor drainage, which is typical for large parts of the Carboniferous Basin, and the climate, which is influenced by the Northumberland Strait.

In order to manage our forest and agricultural industry, we have to determine the physical properties that impose limits on the productivity. It also means that if we would like to enhance the natural productivity of the soils, we should not use synthetic compounds. We must look at natural additions to the nutrient base. For example, lime is used in acid rainplagued forests in Europe, and "whole rock" fertilizers are used by certified organic farmers in North America; these are early indications of what lies ahead. Soils with limited acid rain buffering capacity will become more acid, and toxic elements such as $\mathrm{Pb}, \mathrm{Cd}, \mathrm{As}$, and $\mathrm{Cu}$ will become more mobile in the surficial environment (water, soil, vegetation). Limestone not only buffers acid rain, it improves nutrient tumover rates, and upon weathering, increases the water holding capacity of the soil.

Some of the preliminary work for the New Brunswick 


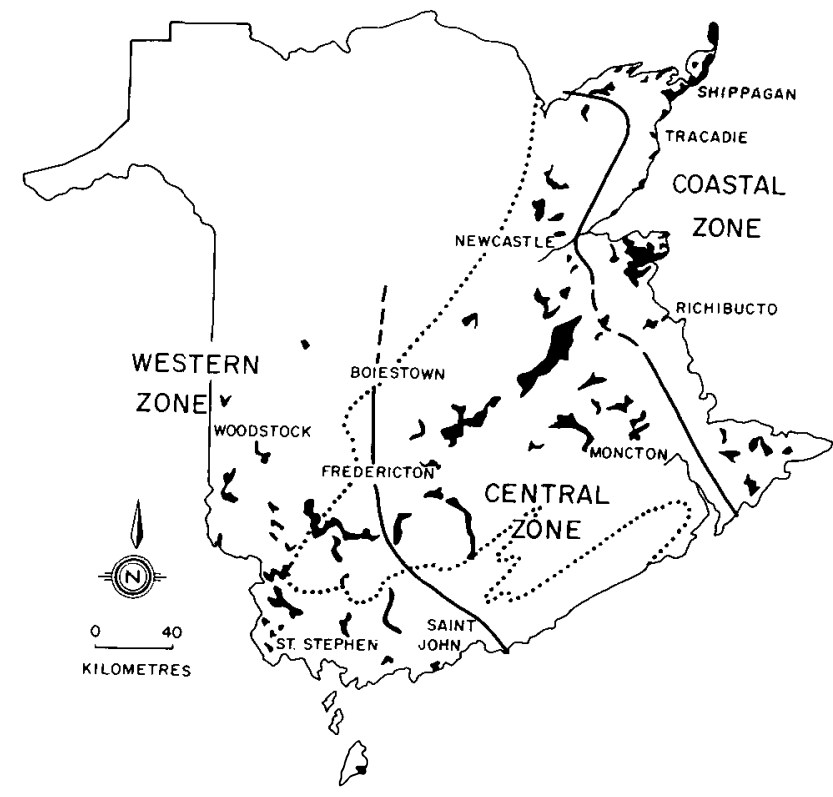

Fig. 10. Distribution of workable peatlands in New Brunswick, and the outline of the Carboniferous Basin (modified from $J$. Thibault, personal communication, 1990).

Forest Site Classification System began with a study of the underlying bedrock and surficial geology (van Groenewoud and Ruitenberg, 1982; Pronk, 1987). Forest management units are given a quality rating based on the nutrient potential and weatherability of the parent material of the soil combined with other site parameters of which drainage is the most important (Fig. 11). Combined, this will put each site in a growth potential class. The growth potential depends mostly on the so-called "major" elements, such as $\mathrm{Na}, \mathrm{Mg}, \mathrm{K}$, and Ca. High Al combined with acid rain does have a detrimental effect on tree growth, and actually poisons the trees. The limiting factor on growth is generally the availability of $\mathrm{N}$, and this is mostly a function of forest floor chemistry. The $\mathrm{pH}$ and humus layer thickness, with its organisms, play a major role in nutrient turnover rate. Poor podzolic soils, found on most igneous rocks and sandstones, generally have low $\mathrm{pH}$ 's and thin humus layers. Soils over limestones and calcareous siltstones, generally have thick humus horizons, little leaching, and rich calcareous $\mathrm{C}$ horizons. Soil formation has taken place since the last ice retreat about 10,000 years ago.

The intensive agricultural and forestry of the last hundred years, with the use of many synthetic fertilizers, pesticides, herbicides and heavy machinery, have left soils extremely susceptible to erosion and denutrification. The sooner we start treating our soils so as to help restore their natural capacity to provide us with crops, the better it will be for our agriculture and forestry. The return of organic matter, as well as mineral nutrients, is essential in retaining the soils natural capacity. Preservation of the natural soil profile as the most efficient way to leach nutrients from the substrate and as a host of living organisms should be stressed.

In this context it is also relevant that life on this planet "recycles" roughly 100 gigatons of carbon annually, which is

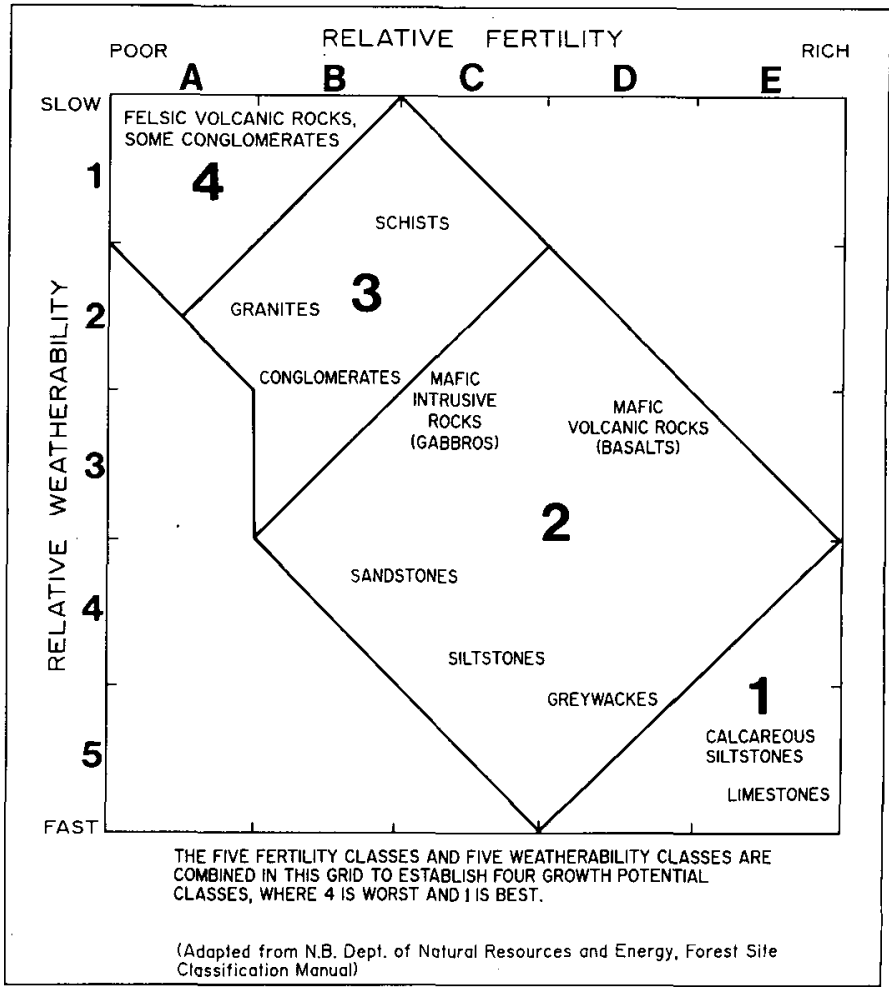

Fig. 11. Geological information forms the base of the New Brunswick Forest Site Classification System that guides forest management.

$\pm 15 \%$ of the total carbon locked up in the earth's living sphere. Man puts in "only" about 5 gigatons. Forest management on a global scale can be a partial solution to greenhouse problems (Weiner, 1990).

\section{Natural Hazards}

Natural hazards include much more than earthquakes and land slides. Volcanic activity, subsidence, coastal erosion, natural radiation, radon gas, and the presence of other geochemical hazards, are all natural hazards. High radon levels in the basement of a Minto (central New Brunswick) school were not initially considered "natural", but many areas in the Carboniferous Basin have naturally high levels as a result of the chemical composition of the local bedrock.

High levels of mercury in soils and waters are commonly found in areas underlain by black shales. Natural (local background) levels in these areas are sometimes higher than those considered acceptable by national environmental standards.

Landslide potential can easily be mapped and landslide risk maps prepared (e.g., Ruitenberg and McCutcheon, 1978). Earthquake forecasting is limited to outlining areas of high potential. Predictions of events are almost impossible based on our present knowledge and technologies. The prediction of volcanic eruptions is not much better (Hickson, 1990).

Mapping of background radiation and presence of radon gas is easily accomplished and should be a requirement of a community plan (see Environment Canada for details in your 
area). Technology is available to minimize the risks related to higher than "acceptable" radon levels. We have to realize that too much of almost anything (even oxygen and water) is a hazard to our health. We must assess what is healthy and what is not, set policies and guidelines, and adapt our behavior accordingly.

\section{Implications and Conclusions}

It is apparent from the available literature that there are many things we do not know about this planet and its processes. This is very graphically described in a recent paper on geospheric forcing of biosphere processes (Fyfe, 1990a). The many processes we do understand help us to discover oil, mineral resources and predict certain events or occurrences, etc. Natural cycles, processes and elements are part of our everyday lives, but are generally poorly understood; and it is the task of earth scientists to share their knowledge with the public, ranging from elementary grades to university programs, and from naturalist and environmental groups to policy makers and politicians. Involvement in planning committees (i.e., the Green Plan, down to local city planning) is essential.

Earth science should play a major role in planning and shaping a sustainable society. In the end, our problems may not necessarily be solved by more knowledge, but more knowledge will make us more capable of assessing the situation in a broader framework and making better informed choices. The final choice will have to be a moral one, not a scientific one.

"Scientists have a responsibility to convey their research in a faithful and intelligible manner, clarifying gaps in knowledge and outlining uncertainties in prediction. And as in many other areas of uncertainties in policy matters, after taking into account the possible consequences for being wrong, it will be better to find out we have been roughly right in due time than to be precisely right too late" (Mykletun, 1990).

\section{ACKNOWLEDGEMENTS}

I thank Les Fyffe and Les Davies for their support, remarks and corrections to the first draft of this paper, David Mossman for asking me to present it as an introduction at the AGS symposium on environmental geology, and the referees B.E. Broster and A.A. Ruitenberg, who improved the manuscript with their remarks and suggestions. Gerry Johnson and Terry Leonard provided assistance with the figures.

Berger, A. 1988. Milankovitch theory and climate. Reviews of geophysics, 26, pp. 624-657.

Berner, R.A. and Lasaga, A.C. 1989. Modelling the geochemical carbon cycle. Scientific American, 260, pp. 74-81.

Bowie, S.H.U. and ThoRNTON, I. (editors). 1985. Environmental Geochemistry and Health. Report to the Royal Society's British National Committee for Problems of the Environment. Reidel, Dordrecht, The Netherlands, 140 p.
Broecker, W.S. and Denton, G.H. 1990. What drives glacial cycles? Scientific American, 261, pp. 49-56.

Crounse, R.G. 1986. Geochemistry and human health in the 1980s. In Applied Geochemistry in the 1980s. Edited by I. Thomton and R.J. Howarth. Graham and Trotman, London, pp. 337-345.

DARNLEY, A.G. 1990. International geochemical mapping: a new global project. In International Geochemical Mapping. Edited by A.G. Darnley and R.G. Garrett. Journal of Geochemical Exploration, 39, pp. 1-13

FYFE, W.S. 1990a. Geosphere forcing: plate tectonics and the biosphere. Paleogeography, Paleoclimatology, Paleoecology, (Global Planetary Change Section), 89, pp. 185-191.

1990b. The International Geosphere/Biosphere Programme and global change: An anthropocentric or an ecocentric future? A personal view. Episodes, 13, pp. 100-102.

Gribbin, J.R. and ReEs, J.S. 1989. Cosmic coincidences: dark matter, humankind, and cosmology. Bantam Books, New York, 302 p.

Groenewoud, H. van and Ruitenbero, A.A. 1982. A productivity oriented forest site classification system for New Brunswick. Environment Canada, Canadian Forestry Service, Maritime Forest Research Centre, Information Report M-X136, 9 p.

HAwKes, H.E. and WeBB, J.S. 1962. Geochemistry in mineral exploration. Harper and Row, New York, 415 p.

Hickson, C. 1990. Can it happen here? GEOS, 19, pp. 1-7.

LINDAEN, R.S. 1990. Some coolness concerning global warming, Bulletin of the American Meteorological Society, 71, pp. 288-299.

Munoall, C. and Mclaren, D.J. 1990. Planet under stress. Royal Society of Canada, Oxford University Press, Toronto, $344 \mathrm{p}$.

Mykletun, J. 1990. Conference on sustainable development. Science and Policy, Conference Report, Global Environmental Change, 1, pp. 77-81.

Pronk, A.G. 1987. Glacial deposits of northern N.B. and their relation to forest productivity. XII INQUA Congress, Ottawa, Program with Abstracts, p. 246.

Ruitenbero, A.A. and McCutcheon, S.R. 1978. Engineering geology of the Lorneville Cove Landslide. New Brunswick Department of Natural Resources and Energy, Mineral Resources Division, Open File Report 78-7, 7 p.

1983. Bedrock, surficial and environmental geology of North Head, Grand Manan, N.B. New Brunswick Department of Natural Resources and Energy, Mineral Resources Division, Open File Report 83-1, 10 p.

SChNeIDER, S.H. 1990. The global warming debate heats up: An analysis and perspective. Bulletin of the American Meteorological Society, 71, pp. 1292-1304.

Thiessen, T. 1990. University taps subterranean heat source. GEOS, 19, pp. 18-19.

Veevers, J.J. 1990. Tectonic-climatic supercycle in the billionyear plate-tectonic eon: Permian Pangean icehouse alternates with Cretaceous dispersed-continents greenhouse. Sedimentary Geology, 68, pp. 1-16.

Violette, G.G. and BRAY, D.I. 1991. Glacial processes explain the probable origin and aid in the exploitation of the Fredericton Aquifer, Fredericton, N.B. Program and abstracts, CANQUA '91, Fredericton, New Brunswick, p. 35.

WeINER, J. 1990. The next one hundred years: Shaping the fate of our living earth. Bantam Books, New York, 312 p. 